\title{
二塚製造部の省エネルギーへの取組事例
}

\section{Energy Conservation Examples of Initiatives Manufacturing Department Futatsuka}

\author{
中越パルプ工業株式会社 ${ }^{* 1}$ 高岡工場 \\ 岡田達郎*2 \\ Tatsurou Okada*2 \\ Takaoka Mill-Futatsuka, Chuetsu Pulp \& Paper Co. Ltd. ${ }^{* 1}$
}

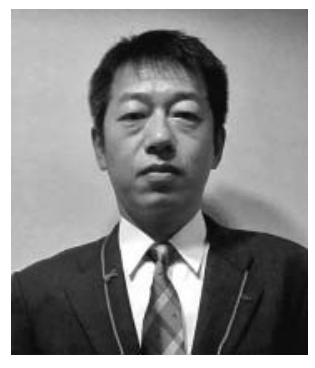

\begin{abstract}
In recent years, oil prices have been rising. Furthermore, after the Tohoku Earthquake (2011), energy-saving is important challenge for not only at a company but at the home. A company must make an effort more by shortage of electric power supply.

Also, in the Manufactuaring department Futatsuka, the energy-saving committee was established in 1990, and we have been implementing energy saving activities every day.

And now, a large-scale investment is reduced and it is not expected improvements in equipment replacement. We are going to build up small results to achieve the target in the difficult situation.

This report introduces the contents of a measure and the examples in energy-saving activities.
\end{abstract}

分類： $\mathrm{U}_{2}$ 省エネルギー一般, $\mathrm{U}_{0}$ その他

\section{1.はじめに}

近年の原油価格高騰, さらに 2011 年の東日本大震災後, 電力需給の逼迫により企業のみならず家庭においても, 省 エネは重要な課題となり, 改めて省エネの重要性が認識さ れている。企業としてもなお一層の努力を積み上げなけれ ばいけない状況である。

二塚製造部においても 1990 年より省エネ委員会を設置 し，日々省エネ活動に取り組んできた。

大型投資が減少してきている現状では大掛かりな設備更 新での改善は期待できず，小さな省エネを積み上げていく しかなく目標達成に苦労しているのが現状だが, その中で 実施してきた省エネ活動の取り組み内容と事例を紹介する。

\footnotetext{
${ }^{* 1}$ T 933-8526 富山県高岡市二塚 3288/3288 Futatuka,

Takaoka-shi, Toyama 933-8526, Japan

${ }^{* 2}$ E-mail : t-okada@chuetsu-pulp.co.jp
}

\section{2. 二塚製造部の概要}

当製造部は昭和 31 年工場建設以来，新聞用紙専抄の工 場として市場のニーズと安定供給を果たすため生産設備の 増設やエネルギー面での充実・強化を行ってきた。また同 時に環境保全活動の取組みを強化し化石燃料から廃棄物由 来燃料使用へ代替を進め $\mathrm{CO}_{2}$ 排出削減を推進している。

\begin{tabular}{|c|c|}
\hline 敷地面積 & $213,000 \mathrm{~m}^{2}$ \\
\hline 従業員数（2012.4） & 124 名 \\
\hline 抄紙機台数 & 2 台 \\
\hline 主要生産品目 & 新聞用紙，出版用紙 \\
\hline 生産量 ～～～～～～～～～ & $18,000 \mathrm{~T} /$ 月 \\
\hline 発電設備 & 2 缶 2 基（合計 $51,900 \mathrm{kW）}$ \\
\hline 購入電力 & 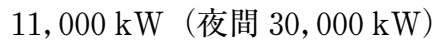 \\
\hline 発電比率 & $70 \%$ \\
\hline
\end{tabular}

\section{3. 二塚製造部 省エネの取り組み}

二塚製造部の省エネ委員会（図 1) は平成 2 年に設置さ れ委員長以下, 各課長 + スタッフ+事務局の計 16 名で構 


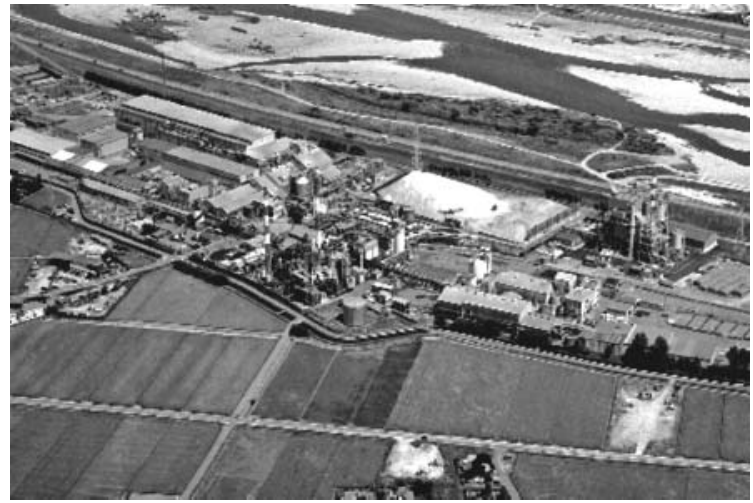

写真 1

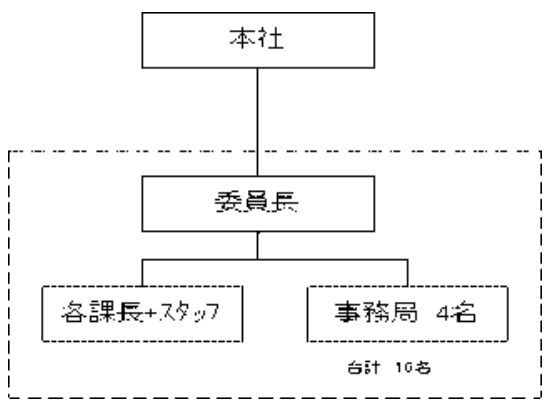

図 1 省エネ委員会組織図

表 1 過去 5 年間の省エネ実績

\begin{tabular}{r|r|r|r|r|r|r}
\hline \multirow{2}{*}{} & \multicolumn{2}{|c|}{ 省重油 $\mathrm{kl} /$ 月 } & \multicolumn{2}{c|}{ 省電力 $\mathrm{kW}$} & \multicolumn{2}{|c}{ 節水 $\mathrm{m}^{3} /$ 日 } \\
\cline { 2 - 7 } & 目標 & 実績 & 目標 & 実績 & 目標 & \multicolumn{1}{c}{ 実績 } \\
\hline 2007 & 100 & 121 & 450 & 458 & 170 & 753 \\
\hline 2008 & 200 & 252 & 300 & 426 & 730 & 846 \\
\hline 2009 & 49 & 0.6 & 200 & 84 & 360 & 1,407 \\
\hline 2011 & 50 & 13.7 & 200 & 250 & 360 & 379 \\
\hline
\end{tabular}

成され省電力, 省重油, 節水の 3 項目を軸に省エネに取り 組んでいる。

今まではインバー夕導入で大きな省エネ実績を上げてき たが，現在は本当にこのインバー夕は必要なのか？この 電動機は停止できないか? また設定は適切か? 等, フ ローの見直しや，運転状況の見直しを行い，さらなる無駄 の排除を実施している。

表 1 における過去 5 年間の省エネ実績が示す通り，概ね 目標を達成しているが年々目標の達成に苦労しているのが 実情である。その中でも省重油に関しては特に苦労してい る。

図 2 に 2011 年度の省電力案件を要因別に分類すると, 数 年前まではインバー夕化が 30-40\% 占めていたものが $4 \%$ しかなく, インバータ化による省電力案件が減って きているのがわかる。代わりに近年は設備停止, 設定值見 直しで $50 \%$ 以上を占めており，昨今の低操業下における

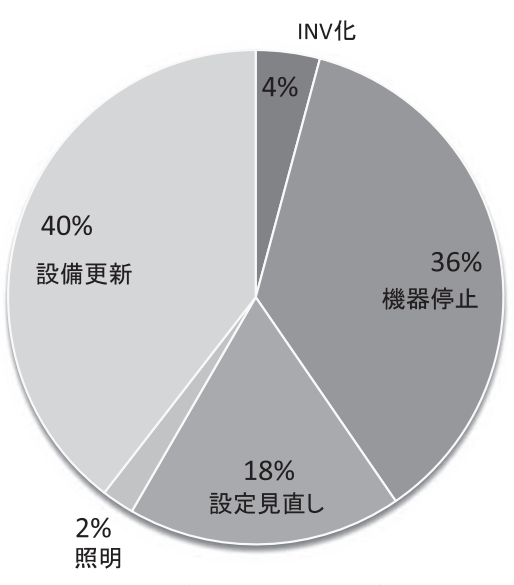

図 22011 年度省電力案件の分類

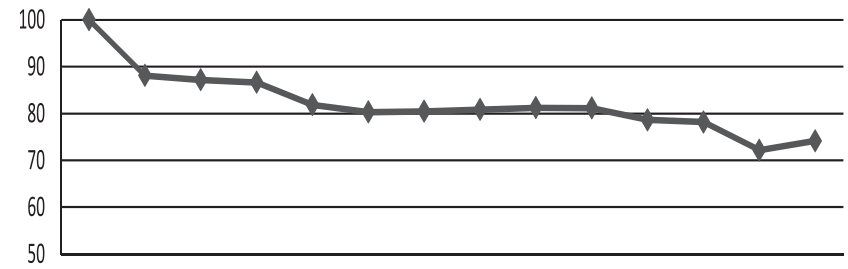

$\begin{array}{llllllllllllll}1990 & 1999 & 2000 & 2001 & 2002 & 2003 & 2004 & 2005 & 2006 & 2007 & 2008 & 2009 & 2010 & 2011\end{array}$

図 3 電力原単位の推移

操業見直し，フロー変更等に目を向けることが必要になっ てきた。

また既設インバータの設定值を見直し最適化を図り，尚 一層の省電力を図ることが重要である。

2011 年は設備更新で $40 \%$ と大きな省エネを達成するこ とができたが，設備投資が高額になり予算の兼ね合いから もなかなか実施できないのが実情である。

図 3 の電力原単位が示す通り，1990 年度比 $25 \%$ 削減と 着実に実績を上げているが，近年の稼働率低下で若干原単 位の悪化傾向にあり，不要機の停止，フローの見直し等ま だまだ無駄の掘り起こしが必要である。

\section{4. 省エネ事例}

\section{1 省 電 力}

\subsection{1 焼却炉コンプレッサの集約化}

図 4 が焼却炉ガスフローである。焼却炉でペーパース ラッジを焼却した排ガスは冷却塔を通過する。続いてマル チサイクロンにて排ガス中の灰分を取り除き, 減温塔で $200^{\circ} \mathrm{C}$ 以下に冷却されたのち, セラミックフィルターで除 塵後，脱硫装置を通過し煙突より排気される。

しかしマルチサイクロンの使用を中止し，バイパスした ことによりセラミックフィルターが目詰まりを起こし，セ ラミックフィルター差圧高によりスラッジ処理ができない 状況になってきた。差圧高対策として，灰を払い落とすパ ルスエアーを増量することで対策を行ってきたが，既設コ ンプレッサ 5 台ではエアーが不足の状態となりコンプレッ サ増設が急務になってきた。

それと同時にセラミックフィルターをやめ，バグフィル ター設備への改造も計画した。改造後にはエアー量が大幅 


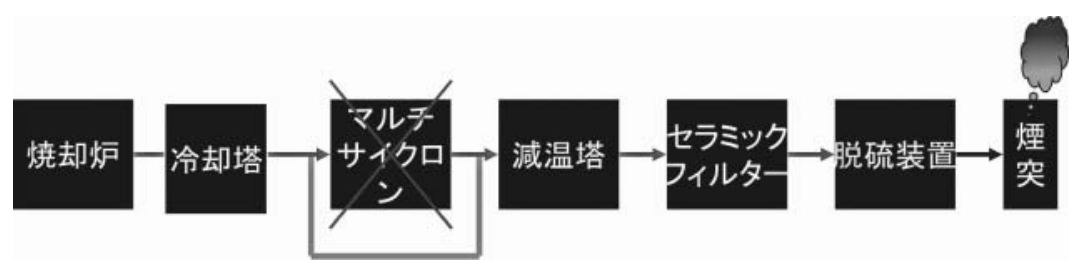

図 4 焼却炉ガスフロー

表 2 コンプレッサ運転実績

\begin{tabular}{c|r|c|r|l}
\hline & $\begin{array}{c}\text { 容量 } \\
\mathrm{kW}\end{array}$ & $\begin{array}{c}\text { 定格 } \\
\left(\mathrm{Nm}^{3} / \mathrm{min}\right)\end{array}$ & $\begin{array}{c}\text { 稼働率 } \\
\%\end{array}$ & 運転開始 \\
\hline \#1 コンプレッサ & 45 & 5.2 & $45 \%$ & $\mathrm{~s} 63.7$ \\
\hline \#2 コンプレッサ & 45 & 5.2 & $91 \%$ & $\mathrm{~s} 63.7$ \\
\hline \#3 コンプレッサ & 45 & 5.2 & $95 \%$ & $\mathrm{~s} 63.10$ \\
\hline \#4 コンプレッサ & 55 & 6.6 & $100 \%$ & $\mathrm{~s} 63.11$ \\
\hline \#5 コンプレッサ & 120 & 18.6 & $106 \%$ & \\
\hline 合計 & 310 & 40.8 & & \\
\hline
\end{tabular}

表 3 予想空気量

\begin{tabular}{c|c|c}
\hline $\begin{array}{c}\text { 通常空気量 } \\
\left(\mathrm{Nm}^{3} / \mathrm{min}\right)\end{array}$ & $\begin{array}{c}\text { 増加後空気量 } \\
\left(\mathrm{Nm}^{3} / \mathrm{min}\right)\end{array}$ & $\begin{array}{c}\mathrm{BF} \text { 後空気量 } \\
\left(\mathrm{Nm}^{3} / \mathrm{min}\right)\end{array}$ \\
\hline 35.0 & 53.6 & 36.6 \\
\hline 実績より & 推定 & 推定 \\
\hline
\end{tabular}

に削減される予定であり, エアー供給量の幅を最大限に広 く計算する必要性が出てきた。

以上の事を考慮し，インバータコンプレッサ機を導入し 省エネを四った。

\section{1 .2 現状把握}

以前はNo.4, 5 コンプレッサをベースに運転し, No. 1，2，3 コンプレッサによる台数制御を実施していた。 マルチサイクロンバイパス工事後, セラミックフィルター 差圧高対策でコンプレッサ稼働率が上昇を続けており，運 転実績（表 2）より 5 台のコンプレッサで約 $35.0 \mathrm{Nm}^{3} / \mathrm{min}$ 使用していたものが, 約 $53 \mathrm{Nm}^{3} / \mathrm{min}$ へ増大し, バグフィ ルター設備に改造後は $36.6 \mathrm{Nm}^{3} / \mathrm{min}$ に減少する予定であ る(表 3)。

\section{1 .3 計画立案}

コンプレッサ導入にあたり，使用空気量と消費電力量の 関係を明確にすることにした。

図 5 は 3 台のコンプレッサを並列運転した場合のモデル ケースであり，消費電力量を 3 種類に分けて説明する。

(1)のグラフでは, 3 台の並列単独運転の場合, 使用空気 量が 0 \%においても，210\%の電力量を消費している。

(2)のグラフでは，(1)の例と同じタイプのコンプレッサを 使用し, 台数制御を行なったときの電力量を表す。グラフ より使用空気量 $300 \Rightarrow 200 \%$ までは 1 台のコンプレッサで ロード・アンロードを繰り返し，200\% 未満では 1 台停止

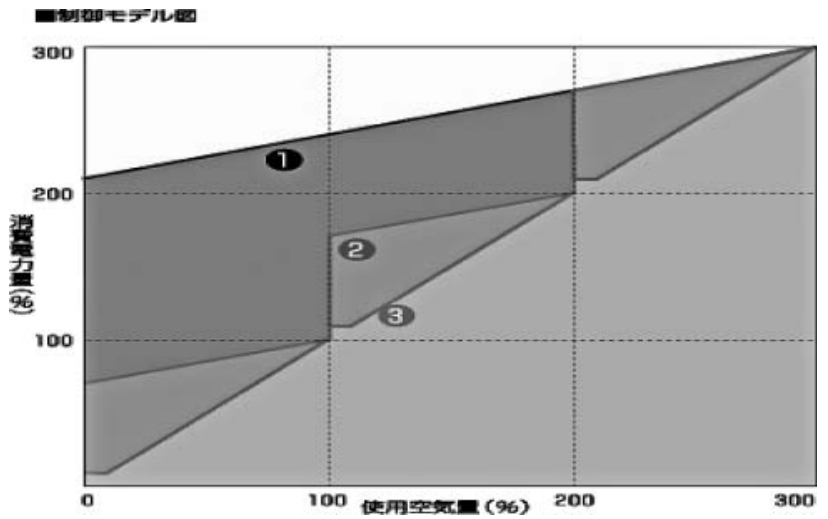

図 5 コンプレッサ 3 台運転時の電力

する。(1)と (2)の相違点として，(1)では 3 台とも運転を継続 しており，(2)では空気量に応じて運転台数を減らし，電力 量も削減している。

(3)のグラフでは， 2 台の商用機と 1 台のインバー夕機の 組み合わせた例であり，インバー夕機とすることで，空気 使用量 $300 \Rightarrow 0 \%$ まで空気量に比例して電力量が削減され る。

以上により，商用コンプレッサとインバータ機でアン ロードが発生しない運用にすれば一番効率が良いことがわ かる。これを当社の設備に当てはめると, No. 5 コンプレッ サと台数削減の為 1 台の大型インバータ機を導入すること にした。

容量はNo. 1〜4 コンプレッサの空気量に $10 \%$ の余裕を みて $160 \mathrm{~kW}$ のインバータ機とした。

運転実績から空気使用量を $35 \mathrm{Nm}^{3} / \mathrm{min}$ と仮定し, 更新

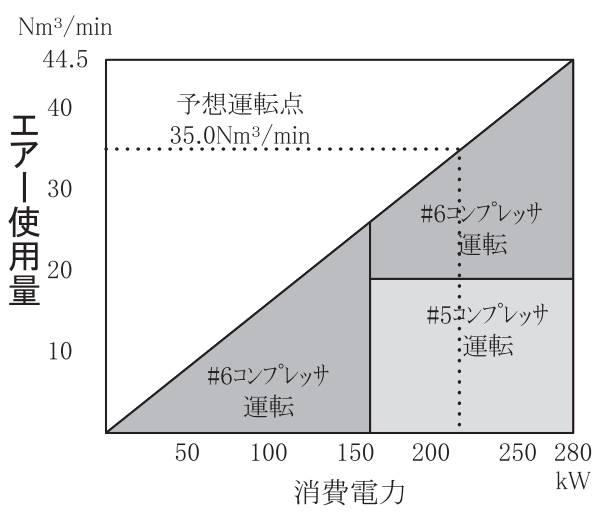

\begin{tabular}{|l|r|r|}
\hline & \multicolumn{1}{|c|}{ 更新前 } & \multicolumn{1}{|c|}{ 新後 } \\
\hline 空気量 $(\mathrm{Nm} 3 / \mathrm{min})$ & 35.0 & 35.0 \\
\hline 電力 $\quad \mathrm{Kw}$ & 287.2 & 約215 \\
\hline
\end{tabular}

図 6 エアー量と電力関係図 


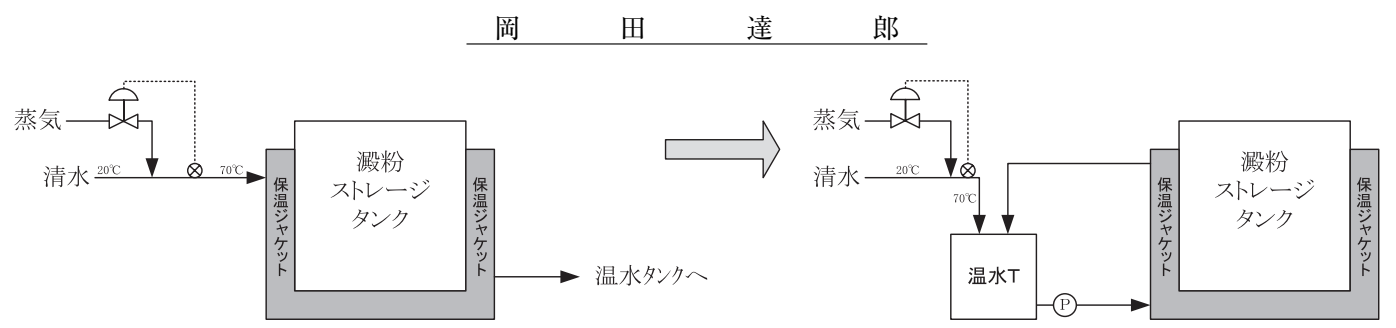

図 7 更新前フロー(左)と更新後フロー(右)

表 4 更新後の実績

\begin{tabular}{l|c|c|c}
\hline & 定格電力 & 改造前 & 改造後 \\
\hline No. 1 & 45 & 20.37 & 0 \\
\hline No. 2 & 45 & 41.68 & 0 \\
\hline No.3 & 45 & 42.48 & 0 \\
\hline No.4 & 55 & 55.2 & 0 \\
\hline No.5 & 120 & 127.47 & 123.31 \\
\hline No.6 & 160 & 設備なし & 78.88 \\
\hline 合計 & & 287.2 & 202.19 \\
\hline メリット & & & $\triangle 85.01 \mathrm{~kW}$ \\
\hline
\end{tabular}

後の電力を図 6 から算出したところ，空気量が変らなけれ ば約 $70 \mathrm{~kW}$ の省電力が達成できる見达みである。

\subsection{4 効果の確認}

コンプレッサ更新前の電力は $287.2 \mathrm{~kW}$ ，バグフィル ター改造, 大型インバータコンプレッサ（以下No.6コン プレッサ）設置後の電力は $202.2 \mathrm{~kW} て ゙$ 省電力としては $85 \mathrm{~kW}$ と予想を上回る実績（表 4）となった。

要因としてはコンプレッサ更新による省電力が約 50 $\mathrm{kW}$ ，バグフィルター化による空気量減が運転実績より約 $5 \mathrm{Nm}^{3} / \mathrm{min}$ で電力に換算すると約 $35 \mathrm{~kW}$ となり, 合わせ て $85 \mathrm{~kW}$ の省電力となった。

この $85 \mathrm{~kW}$ が大きく貢献し年間目標の $200 \mathrm{~kW}$ を達成 することが出来た。

\section{2 省 重 油}

\subsection{1 澱粉ストレージタンク保温蒸気の削減}

従来約 $20^{\circ} \mathrm{C}$ の清水を $70^{\circ} \mathrm{C}$ まで蒸気で加温し, ストレー ジタンク保温ジャケット通過後の温水は温水槽へ回収して いた（図7(左)）。この方法では, 水としては回収するが, 熱は大部分が大気へ放出されてしまう。

そこで，保温ジャケット通過後の温水を専用のタンクに 回収し, 再度 $70^{\circ} \mathrm{C}$ まで加温しジャケット保温に再利用す る循環型とした (図 7 (右) )。その結果, $7.1 \mathrm{~kL}$ 蒸気使用

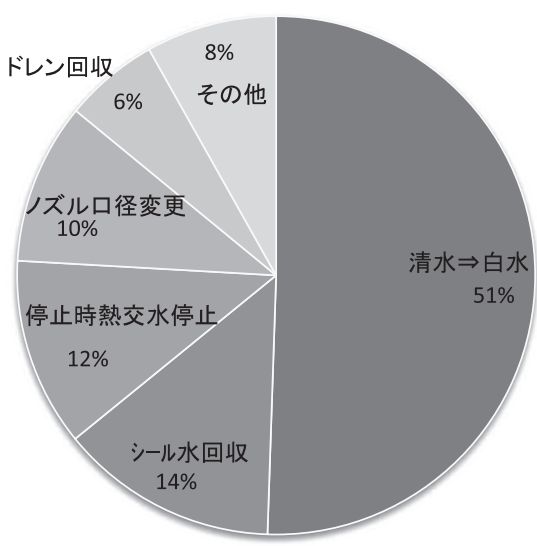

図 82011 年度節水実績
量が削減された。

その他，『加温用ドレン回収』，『省エネトラップに取替』 等で約 $40 \mathrm{kl} /$ 月実績を上げることが出来たが，年間目標の $50 \mathrm{kl} /$ 月を達成することは出来なかった。

\section{3 節水}

節水では『清水を白水に変更』, 『シール水の回収』,『ノ ズル口径の見直し』等の設備改善で $74 \%$ ，『マシン停止時 における熱交清水停止』，『各ドレンの回収』で $26 \%$ を達 成しており，年間目標の $400 \mathrm{~m}^{3} /$ 日を達成することができ た（図 8)。

5. ま と め

今回のコンプレッサ集約化の設備改造は操業を維持する ことが目的であり，省エネには着目されていなかった。仮 にコンプレッサ更新を省エネ工事として試算した場合，回 収月数が長く採用されない可能性が高くなる。しかし設備 改造時に省エネ機器を採用することで省エネを推進してい くことも重要である。近年の低操業下では，小さな無駄を 見つけ排除していくしかない。

今後も更なる省エネルギー活動を継続して電力削減, $\mathrm{CO}_{2}$ 削減, 地球温暖化防止のために少しでも貢献していき たい。 